\title{
EFFECT OF SULPHUR AND PHOSPHATE FERTILIZATION ON GROWTH YIELD AND FRUIT QUALITY OF PEPPER (Capsicum annuum, L.) a- Vegetative growth and chemical constituents of leaves Sarg, Sawsan M.H.*; M.A. Hassan*; S. K. El-Seifi ${ }^{\star}$ and M.K. Rakha** \\ * Hort. Dept., Fac. Agric., Suez Canal Univ. \\ ${ }^{\star *}$ Hort. Res.Inst., Agric. Res. Center
}

\section{ABSTRACT}

Two field experiments were carried out at El-Baramoon Farm, Mansoura Horticultural Research Station, during the summer seasons of 2002 and 2003. The study aimed to investigate the effect of sulphur levels $(0,150$ and $300 \mathrm{~kg} \mathrm{~S} / \mathrm{fed} /)$, and phosphorus fertilization levels $\left(0,30,60\right.$ and $90 \mathrm{~kg} \mathrm{P} \mathrm{P}_{2} \mathrm{O} / \mathrm{fed}$.) and their interactions on the vegetative growth parameters ( plant height, number of branches, number of leaves, leaf area, fresh wt./plant and dry wt./plant), leaf chlorophyll contents and chemical compositions of sweet pepper cv. California Wonder. All tested vegetative growth parameters increased with the increase in sulphur and phosphorus levels. The increments were significant except those of number of branches per plant. The interaction effects showed that the highest level of sulphur (300 $\mathrm{kg} \mathrm{S} / \mathrm{fed}$ ) plus the highest phosphorus level $\left(90 \mathrm{~kg} \mathrm{P} \mathrm{O}_{5} / \mathrm{fed}\right)$ were of superior effects on all the studied vegetative growth parameters.

Chlorophyll a, b, total chlorophyll and chlorophyll $a: b$ ratio significantly increased with increasing either sulphur or phosphorus application levels, over the control. The interaction effects appeared the highest contents of chlorophyll $a, b$ and total chlorophyll with the highest levels of both sulphur (300 kg S/fed) and phosphorus (90 $\mathrm{kg} \mathrm{P}_{2} \mathrm{O}_{5} / \mathrm{fed}$.)

Leaf contents of nitrogen, phosphorus, potassium and sulphur increased significantly with the sulphur and phosphorus fertilization, compared with controls. The increments were in line with the increase in the added sulphur and phosphorus levels. The interaction effects indicated that leaves from plants fertilized with the highest level of sulphur (300 kg S/fed.) plus the highest level of phosphorus $\left(90 \mathrm{~kg} \mathrm{P}_{2} \mathrm{O}_{5} / \mathrm{fed}\right.$ ) resulted in the highest contents of $N, P, K$ and sulphur.

The highest leaf contents of $\mathrm{Fe}, \mathrm{Zn}$ and $\mathrm{Mn}$ were detected in plants fertilized with sulphur at $300 \mathrm{~kg} \mathrm{~S}$./fed. and phosphorus at $60 \mathrm{~kg} \mathrm{P} \mathrm{O}_{5} / \mathrm{fed}$. Leaves of plants treated

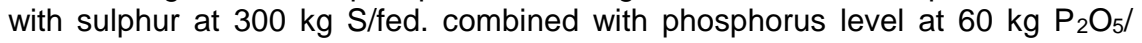
/fed., had the highest contents of Fe, $\mathrm{Zn}$ and $\mathrm{Mn}$.

\section{INTRODUCTION}

Sweet pepper (Capsicum annuum L.) is an important vegetable and condiment crop grown in tropical and subtropical regions of the world for the purpose of exportation and local markets usage. In Egypt, sweet pepper occupied 22853 faddans in 2005, with a production average of 20.05 ton/fed. * Great efforts have been directed toward improving sweet pepper production and quality mainly to increase the exported yield. Several factors are affecting plant growth, among them the nutritional supplies with sulphur and phosphorus fertilization.

Cited after the Economic and Statistical Departement, Ministry of Agriculture, Egypt, 


\section{Sarg, Sawsan M.H. et al}

Several investigations pointed to the presence of a good relationship between sulphur and solubility and availability of phosphorus to plants under alkaline soil (Rivera and Irgazarry, 1984).

Increasing sulphur level improved pepper vegetative growth characters, i.e. plant height, No. of leaves and branches and total dry weight/plant (Taylor, et al.,1984 , Fenn et al., 1987 and Shaheen and Omar, 1989). Pandey and Agrawal (1994) reported that plant height, No. of leaves, leaf area, total (leaf, shoot and plant biomass) of tomato plants were greatly enhanced by sulphur application. They also reported that $S$ treated plants allocated a greater proportion of their assimilates for growth and development of photosynthetic organs.

Many investigators confirmed that application of elemental sulphur increased all growth parameters and leaf chlorophyll content ( Topcuoglu and Yalcin, 1997 on tomato ; Sawan and Rizk, 1998 on eggplant ; Hewedy, 1999 on tomato ; Smatanova et al., 2004 on pepper and El-Morsy, 2005 on garlic).

Mostafa et al., (1990) found that solubility of $\mathrm{Fe}$ and $\mathrm{Mn}$ was clearly increased in different soil layers as a result of $S$ incorporation with soil.

Elemental sulphur is the most effective of the soil acidulents. By the end of $\mathrm{S}$ oxidation process, sulphuric acid is formed and soil $\mathrm{pH}$ starts to drop down causing an increase in the availability and uptake of $\mathrm{N}, \mathrm{P}, \mathrm{K}, \mathrm{S} \mathrm{Ca}, \mathrm{Fe}$, $\mathrm{Zn}, \mathrm{Mn}$ and other elements in many vegetable crops (Rahman and Hoque, 1994 on eggplant ; Tisdale et al., 1995 ; Vinay et al., 1995 on garlic ; Topcuoglu and Yalcin, 1997 on tomato ; El-Fayoumy and El-Gamal, 1998 on potato and Kowalska , 2005 on tomato).

Phosphorus is closely concerned with vital growth processes which are essential in all living cells. It is a constituent of nucleic acid and nuclei; it plays a good role in plant metabolism, structure and reproduction processes that can not be replaced by any other element. Phosphorus is indirectly associated with all the biochemical reactions in plants. It is associated with both the accumulation and release of energy for plant metabolic functions. In addition it is known that phosphates are necessary and intimately involved in photosynthesis, in the utilization of sugars, starch and the formation of meristematic tissues (Gardener et al., 1985).

Phosphorus application considerably improved vegetative growth of pepper plants. Vegetative growth parameters i.e. plant height, number of leaves, number of branches, leaf area, both fresh and dry weight of shoots and leaf chlorophyll content increased with the increase in the level of applied phosphorus (Reuveni et al., 1998 ; Kaya et al., 2003 and Alabi, 2006). Many investigators reported that the availability and uptake of $\mathrm{N}, \mathrm{P}, \mathrm{K} \mathrm{Ca}, \mathrm{Mg}, \mathrm{S}$, $\mathrm{Fe}, \mathrm{Zn}$ and $\mathrm{Mn}$ were markedly increased in pepper plants as a result of increasing P fertilization level (Olsen et al., 1993 , Davies et al., 1999 , Kaya et al., 2003 and Schroeder and Janos, 2005)

Regarding the interaction effect of $\mathrm{P}$ and $\mathrm{S}$, many investigators illustrated that application of $P$ and $S$ was of a great effect in maximizing different vegetative growth parameters, chlorophyll content and leaf mineral contents (Shaheen et al., 1989 a on broad bean; Olsen et al., 1993 on pepper; Gopal et al., 2003. on tomato, and Jaggi et al., 2003 on pepper). 


\section{MATERIALS AND METHODS}

Two field experiments were carried out at El-Baramoon Farm of Mansoura Horticultural Research Station, during the two successive summer seasons of 2002 and 2003. This work aimed to study the effect of mineral fertilization with different levels of sulphur, phosphorus and their interactions on vegetative growth, leaf chlorophyll contents and chemical compositions of sweet pepper plants(Capsicum annuum L. cv. California Wonder), under clay soil.

On March $20^{\text {th }}$, of both 2002 and 2003 seasons, sweet pepper seeds cv. California Wonder were sawn in the nursery in $2 \times 2 \mathrm{~m}$. beds. After six weeks, seedlings were transplanted to the field, $30 \mathrm{~cm}$ apart on one side of the ridge. The experimental unit was consisted of 4 rows, each of $4 \mathrm{~m}$ long and $0.7 \mathrm{~m}$ width, with an area of $11.2 \mathrm{~m}^{2}$.

\section{Experimental design and treatments:}

A complete randomized block design in split plot system, with 3 replications was adopted. Main plots were occupied with sulphur levels $(0$, 150 and $300 \mathrm{~kg} \mathrm{~S} / \mathrm{fed}$.), whereas phosphorus levels $(0,30,60$ and $90 \mathrm{~kg}$ $\mathrm{P}_{2} \mathrm{O}_{5} / \mathrm{fed}$.) were placed in the subplots. The experiment includes 12 treatments, which were the combination of 3 sulphur $\times 4$ phosphorus levels. Sulphur was applied once before transplanting and during soil preparation, whereas phosphorus was applied as Ca-superphosphate (15.5\%) in two equal doses, before transplanting and 30 days later.

All plots were fertilized equally with $\mathrm{N}$ at $200 \mathrm{~kg} \mathrm{~N} / \mathrm{fed}$. using ammonium sulphate $(20.5 \% \mathrm{~N})$ and $50 \mathrm{~kg} \mathrm{~K} \mathrm{~K}_{2} \mathrm{O} / \mathrm{fed}$. as potassium sulphate $\left(48 \% \mathrm{~K}_{2} \mathrm{O}\right)$. All plants received similar cultural practices as commonly recommended.

\section{Recorded data:}

Vegetative growth:

Three representative plants from each plot were randomly picked up at 90 days after transplanting to measure, plant height $(\mathrm{cm})$, number of branches/ plant, number of leaves/ plant, leaf area/ plant (according to the method of Koller, 1972) and fresh and dry weight/ plant (kg).:

\section{Photosynthetic pigments:}

Samples of $0.2 \mathrm{gm}$ fresh leaves were used for extraction and determination of chlorophylls $a$ and $b$ by using spectrophotometer (Mackinny, 1941).

\section{Elemental composition of leaves:}

Leaf samples were used to determine, total nitrogen (\%), phosphorus (\%), potassium (\%) and sulphur concentration (\%), according to Black (1983), Watanab and Olsen (1965), Jackson (1965) and Page (1982), respectively. Meanwhile, $\mathrm{Fe}, \mathrm{Mn}$ and $\mathrm{Zn}$ were measured in the same leaf samples, using atomic absorption spectrophotometer, according to the method of Chapman and Partt (1961).

All collected data were statistically subjected to analysis of variance and means were separated using Least significant difference test as described by Snedecor and Cochran (1980).

Mechanical and chemical analysis of the experimental soil were conducted at Mansoura Center of Soil Improvement, Mansoura, Egypt, 
according to methods of Black (1965) and Page (1982). The analysis data are shown in Table (1).

Table (1): Physical and chemical analysis of the experimental soil, during 2002 and 2003 seasons.

\begin{tabular}{|c|c|c|}
\hline \multirow{2}{*}{ Soil properties } & \multicolumn{2}{|c|}{ Season } \\
\hline & 2002 & 2003 \\
\hline \multicolumn{3}{|l|}{ Physicapenanalysis } \\
\hline Coarse sand\% & 1.92 & 2.12 \\
\hline Fine sand\% & 22.57 & 22.79 \\
\hline Silt \% & 26.11 & 25.96 \\
\hline Clay \% & 49.40 & 49.13 \\
\hline Soil type & Clay & Clay \\
\hline \multicolumn{3}{|l|}{ Chemical analysis } \\
\hline Total nitrogen \% & 0.12 & 0.15 \\
\hline Available P (ppm) & 7.15 & 7.95 \\
\hline Exchangeable K (ppm) & 215 & 229 \\
\hline $\mathrm{CaCO}_{3} \%$ & 2.80 & 2.75 \\
\hline Organic matter \% & 1.90 & 2.10 \\
\hline $\mathrm{EC}\left(\mathrm{mmhos} / \mathrm{cm}, 25^{\circ} \mathrm{C}\right)$ & 1.25 & 1.29 \\
\hline $\mathrm{pH}(1: 2: 5 \mathrm{w} / \mathrm{v})$ & 8.02 & 7.90 \\
\hline \multicolumn{3}{|l|}{ Soluble anions (meq/L) } \\
\hline 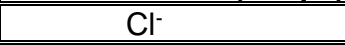 & $\begin{array}{c}.49 \\
\end{array}$ & 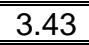 \\
\hline $\mathrm{HCO}_{3}$ & 3.15 & 3.18 \\
\hline $\mathrm{CO}_{3}{ }^{-}$ & 0.00 & 0.00 \\
\hline $\mathrm{SO}_{4}^{-}$ & 5.11 & 5.18 \\
\hline \multicolumn{3}{|l|}{ Soluble cations (meq/L) } \\
\hline$\overline{\mathrm{C \textrm {Ca } ^ { + + }}}$ & 24.00 & 3.97 \\
\hline $\mathrm{Mg}^{++}$ & 1.29 & 1.27 \\
\hline $\mathrm{Na}$ & 1.19 & 1.22 \\
\hline $\bar{K}$ & 5.27 & 5.33 \\
\hline \multicolumn{3}{|c|}{ Available micronutrients (ppm) } \\
\hline $\mathrm{Fe}$ & 3.59 & 3.63 \\
\hline $\mathrm{Zn}$ & 1.31 & 1.29 \\
\hline$\overline{\mathrm{Cu}}$ & 0.53 & 0.55 \\
\hline $\mathrm{Mn}$ & 1.48 & 1.43 \\
\hline
\end{tabular}

\section{RESULTS AND DISCUSSION}

Vegetative growth parameters:

\section{Effect of sulphur}

The effect of sulphur and phosphorus levels and their interactions on plant height, number of branches, number of leaves, leaf area/plant, fresh weight and dry weight/plant are shown in Tables (2 and 3 ).

Data presented in Table (2) show that plant height and number of leaves were significantly increased with increasing sulphur levels from zero up to $300 \mathrm{~kg}$. S/fed. However, the increase in number of branches did not reach the level of significance. This was true in both seasons of the study. 
Table (2). Effect of sulphur, phosphorus and their interactions on plant height (cm) No. of branches and No. of leaves, during 2002 (S1) and 2003 (S2) seasons.

\begin{tabular}{|c|c|c|c|c|c|c|}
\hline \multirow{2}{*}{\begin{tabular}{|l|} 
Characters \\
Season
\end{tabular}} & \multicolumn{2}{|c|}{$\begin{array}{l}\text { Plant height } \\
\text { (cm) }\end{array}$} & \multicolumn{2}{|c|}{ No. of branches } & \multicolumn{2}{|c|}{ No. of leaves } \\
\hline & S1 & S2 & S1 & S2 & S1 & S2 \\
\hline \multicolumn{7}{|l|}{ Treatment } \\
\hline \multicolumn{7}{|l|}{ S (kg S/fed) } \\
\hline Control & 63.33 & 59.49 & 10.20 & 9.08 & 39.65 & 41.20 \\
\hline 150 & 70.95 & 66.16 & 10.41 & 9.38 & 53.19 & 50.61 \\
\hline 300 & 77.24 & 69.17 & 10.66 & 10.29 & 65.30 & 61.79 \\
\hline L.S.D. (5\%) & 2.53 & 1.24 & N.S & N.S & 2.95 & 3.41 \\
\hline \multicolumn{7}{|l|}{$\mathbf{P}\left(\mathrm{kg} \mathrm{P}_{2} \mathrm{O}_{5} / \mathrm{fed}\right)$} \\
\hline Control & 62.13 & 57.05 & 9.90 & 8.60 & 24.37 & 32.57 \\
\hline 30 & 67.95 & 64.63 & 10.10 & 9.08 & 45.70 & 48.92 \\
\hline 60 & 73.99 & 67.63 & 10.67 & 9.94 & 64.64 & 59.98 \\
\hline 90 & 77.95 & 70.44 & 11.02 & 10.72 & 76.16 & 66.33 \\
\hline L.S.D. (5\%) & 1.84 & 1.75 & N.S & N.S & 3.86 & 2.26 \\
\hline \multicolumn{7}{|c|}{ Interactions } \\
\hline 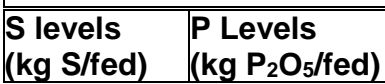 & & & & & & \\
\hline Control & 57.25 & 54.23 & 9.80 & 8.38 & 14.31 & 25.18 \\
\hline 30 & 61.75 & 59.38 & 9.95 & 8.50 & 30.81 & 39.42 \\
\hline Gontret & 65.33 & 60.10 & 10.19 & 9.13 & 51.92 & 46.28 \\
\hline (1) & 69.00 & 64.25 & 10.85 & 10.30 & 61.56 & 53.93 \\
\hline Control & 63.03 & 58.18 & 9.93 & 8.46 & 26.38 & 32.19 \\
\hline Eontror & 67.00 & 64.13 & 9.97 & 8.62 & 41.46 & 48.17 \\
\hline 60 & 75.40 & 70.25 & 10.82 & 9.75 & 66.38 & 56.36 \\
\hline 90 & 78.38 & 72.08 & 10.93 & 10.70 & 78.55 & 65.73 \\
\hline Control & 66.13 & 58.75 & 9.97 & 8.96 & 32.41 & 40.33 \\
\hline (1) & 75.10 & 70.40 & 10.39 & 10.12 & 64.82 & 59.18 \\
\hline 60 & 81.25 & 72.53 & 11.00 & 10.93 & 75.61 & 68.29 \\
\hline 90 & 86.48 & 75.00 & 11.29 & 11.15 & 88.36 & 79.34 \\
\hline L.S.D. (5\%) & 3.18 & 3.03 & N.S & N.S & 6.69 & 3.91 \\
\hline
\end{tabular}

Results of Table (3) declare that leaf area/plant, fresh weight and dry weight/plant, increased significantly concurrently with the increase of sulphur levels from zero, 150 up to $300 \mathrm{~kg} \mathrm{~S} / \mathrm{fed}$. The increase in vegetative growth parameters could be due to the fact that sulphur increased the capacity of plant in building metabolites ( Shaheen et al. 1989a) on or to the helpful effect of sulphur on activating vegetative growth, which in turn increased the number of leaves and branches (Omar et al. 1990).

Results are in harmony with the findings of Shaheen and Omar (1989) on sweet pepper ; Lopez-Moreno et al. (1996) on tomato; Sawan and Rizk (1998) on egyplant; Hewedy (1999) on tomato ; Gopal et al. (2003) on tomato; Smatanova et al. (2004) on pepper and El-Morsy (2005) on garlic.

\section{Effect of phosphorus:}

Data presented in Table (2) show that plant height and number of leaves increased significantly with increasing phosphorus levels. This increase was 
corresponding to the increase in $\mathrm{P}$ rate from zero up to $90 \mathrm{~kg} \mathrm{P}_{2} \mathrm{O}_{5} / \mathrm{fed}$. Number of branches was not significantly increased with increasing phosphorus levels compared with control. This was true in the two seasons of the study.

Data shown in Table (3) indicate that application of phosphorus levels markedly increased leaf area/plant, fresh weight as well as dry weight/plant. Plants received P-fertilizer were generally better than those of the control. Tincrease in the rate of applied $P$ from 30 to $90 \mathrm{~kg} \mathrm{P} \mathrm{P}_{5} / \mathrm{fed}$ caused stimulative effect on plant growth and the highest two levels $(60$ and $90 \mathrm{~kg}$ $\mathrm{P}_{2} \mathrm{O}_{5} / \mathrm{fed}$.) were the superior treatments, where they significantly increased leaf area/plant and shoot fresh and dry weights/plant. This was evident in both seasons. The positive effect of phosphorus on vegetative growth may be due to the beneficial effect of P-element on the activation of photosynthesis and metabolic processes of organic compounds in plants and hence increasing plant growth (Gardener et al., 1985). These results are in agreement with those of Shaheen et al.,(1989 b); Lopez-Moreno et al. (1996); Reuveni et al. (1998); Nigri et al. (1999); Broschat and Klock (2000); Kaya et al. (2003) and Alabi (2006). They all concluded that P-supplementation to pepper plants improved their growth parameters i.e. plant height, number of leaves, shoot fresh and dry weights and leaf area/plant.

\section{Effect of interaction:}

Data in Table (2) cleare that application of $S$ and $P$ in combination exhibited significant increase in plant height and number of leaves. However, the increase in number of branches as a result of $S+P$ application was not significant in the two seasons. Data presented in Table (3) show that leaf area/plant, fresh weight and dry weight increased significantly with the increase in the combined sulphur and phosphorus levels. It is clear from the Data of Tables (2 \& 3) that the highest rates $\left(300 \mathrm{~kg} \mathrm{~S}+90 \mathrm{~kg} \mathrm{P} \mathrm{O}_{5} / \mathrm{fed}\right)$ gave the best results in all studied parameters. The increase in plant growth parameters could be due to the effect of sulphur element on soil $\mathrm{pH}$ reduction, to the point that helps in increasing the availability of some nutrient elements such as $\mathrm{P}, \mathrm{Fe}, \mathrm{Zn}, \mathrm{Mn}$ and $\mathrm{Cu}$ which were reflected on plant uptake and growth (Dahdouh et al. (1993) ; Mehana (1994); Mehana and Farag (2000) and El-Morsy (2005). Similar results were obtained by Olsen et al. (1993) who indicated that application of $P+S$ increased the dry weight of leaves and stems of bell pepper. Hewedy (1999) on tomato; Mahmoud (2000) on eggplant, found that application of $S(1000 \mathrm{~kg} / \mathrm{fed})$ in combination with $0.2 \% \mathrm{P}$ gave the highest records for number of branches and plant height. Youssef (2002) found that application of $50 \mathrm{~kg} \mathrm{~S} / \mathrm{fed}+60 \mathrm{~kg} \mathrm{P} / \mathrm{fed}$ improved plant height and number of leaves/plant. Gopal et al. (2003) illustrated that the highest $\mathrm{P}$ and $\mathrm{S}$ levels restored growth of tomato plants. 
Table (3). Effect of sulphur, phosphorus and their interactions on leaf area/plant $\left(\mathrm{m}^{2}\right)$, fresh weight/plant $(\mathrm{gm})$ and dry weight/plant $(\mathrm{gm})$ during $2002\left(S_{1}\right)$ and $2003\left(S_{2}\right)$ seasons.

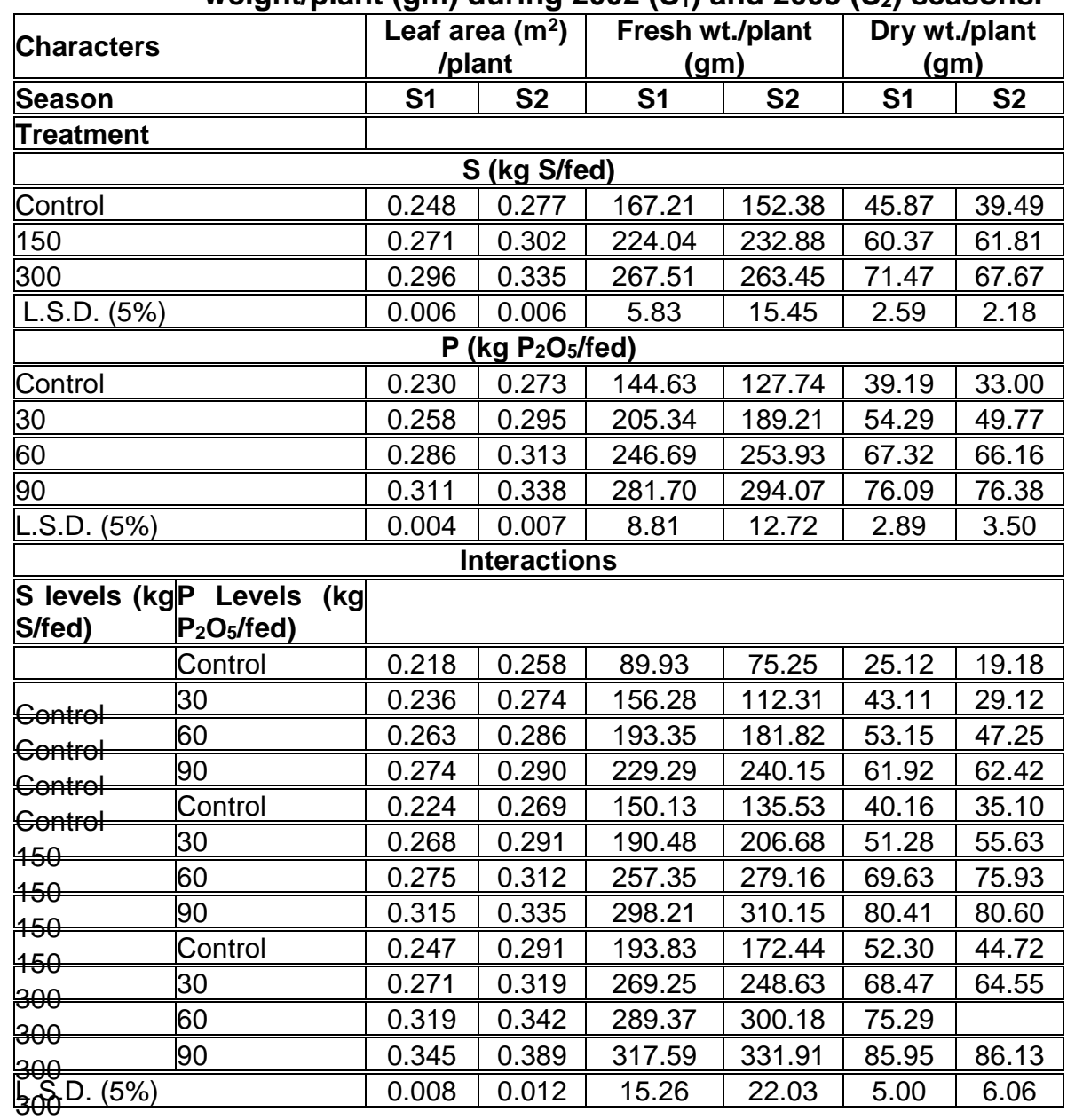

\section{Photosynthetic leaf pigments:}

\section{Effect of sulphur:}

The effect of sulphur on chlorophyll a, b, total chlorophyll and chlorophylls $a / b$ ratio are presented in Table (4). Data declared that chlorophyll $\mathrm{a}, \mathrm{b}$, total and $\mathrm{a} / \mathrm{b}$ ratio significantly increased with increasing sulphur application levels. These results may be due to the beneficial effect of the sulphur as one of many elements required for plant growth and its necessary for the formation of protein and chlorophylls (Morris et al., 1984 and Hewedy 1999). The essential role of $S$ in the synthesis of chlorophyll has been observed by Dietz (1989) on spinach where he suggested that the reduction in chlorophyll $a$ and $b$ in case of $S$ deficiency, might be due to accelerated breakdown of chlorophyll and decomposition of chloroplasts under low $S$ conditions. The obtained results are in accordance with those of, 
Topcuoglu and Yalcin (1997) on tomato, Sawan and Rizk (1998) on eggplant and Gopal et al. (2003) on tomato.

\section{Effect of phosphorus:}

Results of Table (4) illustrate that chlorophyll a, b, total and $a / b$ ratio increased significantly with increasing phosphorus levels. This was true in the two seasons. These results are coincided with those of Kaya et al. (2003) and El-Tohamy et al. (2004) confirmed that application of phosphate to the root zone of pepper plants increased chlorophyll content over the control.

\section{Effect of interaction:}

Data in Table (4) indicated that the leaves of plants treated with the highest levels of both sulphur (300 kg/fed) and phosphorus $(90 \mathrm{~kg} / \mathrm{fed})$ had the highest contents of chlorophyll $\mathrm{a}, \mathrm{b}$ and total chlorophyll, in the two seasons.

Table (4). Effect of sulphur, phosphorus and their interactions on chl.a, chl. b, total chl. (mg/100 gm D.W.) and a/b ratio, during $2002\left(S_{1}\right)$ and $2003\left(S_{2}\right)$ seasons.

\begin{tabular}{|c|c|c|c|c|c|c|c|c|}
\hline \multirow{2}{*}{\begin{tabular}{|l} 
Characters \\
Season
\end{tabular}} & \multicolumn{2}{|c|}{$\begin{array}{c}\text { Chl.a (mg/10 } \\
\text { gm D.W) }\end{array}$} & \multicolumn{2}{|c|}{$\begin{array}{c}\text { Chl.b(mg/100 } \\
\text { gm.D.W) }\end{array}$} & \multicolumn{2}{|c|}{$\begin{array}{l}\text { Total chl.(mg/ } \\
100 \mathrm{gm} . \mathrm{D} . \mathrm{W})\end{array}$} & \multicolumn{2}{|c|}{ a/b ratio } \\
\hline & S1 & S2 & S1 & S2 & S1 & 2 & S1 & S2 \\
\hline \multicolumn{9}{|l|}{ Treatments } \\
\hline \multicolumn{9}{|c|}{$\overline{S \text { (kg S/fed) }}$} \\
\hline Control & 2.23 & 2.54 & 1.32 & 1.47 & 3.55 & 4.01 & 1.69 & 1.73 \\
\hline 150 & 2.53 & 2.81 & 1.37 & 1.50 & 3.90 & 4.31 & 1.85 & 1.87 \\
\hline 300 & 3.10 & 3.48 & 1.52 & 1.62 & 4.62 & 5.10 & 2.04 & 2.15 \\
\hline L.S.D. (5\%) & 0.07 & 0.09 & 0.03 & 0.03 & 0.09 & 0.12 & 0.01 & 0.04 \\
\hline \multicolumn{9}{|c|}{$\bar{P}\left(\mathrm{~kg} \mathrm{P}_{2} \mathrm{O}_{5} / \mathrm{fed}\right)$} \\
\hline Control & 2.36 & 2.74 & 1.29 & 1.45 & 3.65 & 4.19 & 1.83 & 1.89 \\
\hline 30 & 2.47 & 2.85 & 1.34 & 1.50 & 3.81 & 4.35 & 1.84 & 1.90 \\
\hline 60 & 2.71 & 2.95 & 1.44 & 1.53 & 4.15 & 4.48 & 1.88 & 1.93 \\
\hline 90 & 2.93 & 3.22 & 1.54 & 1.64 & 4.47 & 4.86 & 1.90 & 1.96 \\
\hline L.S.D. (5\%) & 0.05 & 0.06 & 0.03 & 0.02 & 0.08 & 0.08 & 0.01 & 0.01 \\
\hline \multicolumn{9}{|c|}{ Interactions } \\
\hline \multicolumn{9}{|c|}{\begin{tabular}{|l|l|l|}
$\begin{array}{l}\text { S levels } \\
\text { S/fed) }\end{array}$ & $\left(\mathrm{kg} \mid \begin{array}{l}\mathrm{P} \\
\mathrm{P}_{2} \mathrm{O}_{5} / \mathrm{fed}\end{array}\right.$ \\
\end{tabular}} \\
\hline Control & 2.00 & 2.40 & 1.21 & 1.41 & 3.21 & 3.81 & 1.65 & 1.70 \\
\hline Control & 2.15 & 2.51 & 1.29 & 1.46 & 3.49 & 3.97 & 1.67 & 1.72 \\
\hline Control & 2.27 & 2.56 & 1.34 & 1.48 & 3.61 & 4.04 & 1.69 & 1.73 \\
\hline Control & 2.48 & 2.70 & 1.46 & 1.55 & 3.94 & 4.25 & 1.70 & 1.74 \\
\hline Control & 2.32 & 2.66 & 1.28 & 1.44 & 3.60 & 4.10 & 1.81 & 1.85 \\
\hline 450 & 2.41 & 2.74 & 1.31 & 1.47 & 3.72 & 4.21 & 1.84 & 1.86 \\
\hline 60 & 2.60 & 2.81 & 1.40 & 1.49 & 4.00 & 4.30 & 1.86 & 1.89 \\
\hline 90 & 2.81 & 3.03 & 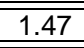 & 1.59 & 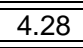 & 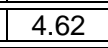 & 1.88 & 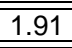 \\
\hline Control & 2.78 & 3.17 & 1.37 & 1.51 & 4.15 & 4.68 & 2.02 & 2.10 \\
\hline 30 & 2.87 & 3.31 & 1.41 & 1.56 & 4.28 & 4.87 & 2.04 & 2.12 \\
\hline 60 & 3.27 & 3.50 & 1.59 & 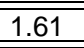 & 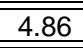 & 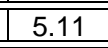 & 2.06 & 2.17 \\
\hline 300 & 3.50 & 3.93 & 1.69 & 1.79 & 5.19 & 5.72 & 2.10 & 2.20 \\
\hline bof.D (5\%) & 0.09 & 0.11 & 0.05 & 0.04 & 0.14 & 0.15 & 0.01 & 0.02 \\
\hline
\end{tabular}


The lowest chlorophyll contents appeared in the leaves of control plants. Gopal et al. (2003) indicated that P and S at low rates drastically

reduced the concentration of chlorophylls $a$ and $b$ in tomato plants, and reduced Hill reaction activity in either low $\mathrm{P}$ or low $\mathrm{S}$. This might be due to involvement of $S$ in chlorophyll synthesis and thus indirectly affecting photosynthesis. However, the lowered Hill activity in S deficiency was raised by combining with P. Similar results were obtained by Lauer et al. (1989) on soybean.

\section{Leaf contents of macroelements:}

Effect of sulphur:

Data in Table (5) show that nitrogen, phosphorus, potassium and sulphur contents in the leaves were significantly increased with the increase in soil application of sulphur levels as compared with control plant leaves. The high $\mathrm{N}, \mathrm{P}, \mathrm{K}$ and $\mathrm{S}$ contents in the treated plants could explain the enhancement in the vegetative growth of these plants as reported in Table (1) due to the essential role of these macro elements in the various metabolic processes. This was evident in the two seasons.

Results of the first season showed higher potassium leaf content than those of the second one. These increments were observed with the different levels of sulphur and with the leaves of untreated plants.

The increments of $\mathrm{N}, \mathrm{P}, \mathrm{K}$ and $\mathrm{S}$ contents in the leaves as a result of $\mathrm{S}$ application had explained by El-Fayoumy and El-Gamal (1998) on potato, where they stated that S-application significantly increased P-extracted from soil and available $P$ in the surface layers. They also confirmed that, $P$ absorption and uptake by plants was increased by $S$ application rates. Rahman and Hoque (1994) on eggplant and Youssef (2002) on pea, reported that addition of sulphur decreased $\mathrm{pH}$ of soil extract and increased the availability of many elements in rooting zone, which in turn increased their absorption by plants. Pandey and Agrawal (1994) ; Topcuoglu and Yalcin (1997) on tomato ; Radwan and Tawfik (2004) ; El-Ghamry et al., (2005) on potato and Kowalska (2005) on tomato came to the same conclusion.

\section{Effect of phosphorus:}

Data presented in Table (5) declare that nitrogen, phosphorus, potassium and sulphur percent in the leaves increased significantly with increasing phosphorus levels. The increments were corresponded with each level of phosphorus application. These results are in agreement with those of Davies et al. (1999) on Capsicum annuum, El-Morsy et al. (2002) on potato, Kaya et al. (2003) and Muthumanickam (2003) on pepper plant. They all concluded that increasing phosphorus application level, increased the availability of NPK elements.

\section{Effect of interaction:}

The interaction effects of sulphur and phosphorus on the leaf nitrogen contents (Table 5) indicated that the leaves of plants treated with the highest sulphur level (300 kg S/fed) and the highest phosphorus level $(90 \mathrm{~kg}$ $\mathrm{P}_{2} \mathrm{O}_{5} /$ fed) gained the highest nitrogen $(4.15 \%$ and $4.23 \%)$, and phosphorus $(0.656 \%$ and $0.686 \%)$ contents in the first and second seasons, respectively, compared with control plants that contained the lowest nitrogen $(3.13 \%$ and 
$3.33 \%)$ and phosphorus $(0.311 \%$ and $0.354 \%)$ contents in the first and second seasons, respectively.

The increase in $\mathrm{P}$ content in the leaves may be due to the influence of $\mathrm{S}$, which plays an important role in increasing availability and uptake of phosphorus (Yousry et al., 1984 and Gendy et al., 1995), by increasing the level of phosphorus from the bulk soil to rhizosphere and stimulating its uptake by reducing soil pH (Khater, 1981 and Al-Rawi and Tajuldeen, 1985). Furthermore, sulphur plays a role in improving soil water relations and increasing root growth and roots penetration depth (Hilal, 1990, El-Fayoumy, 1996) on faba bean and Mazrouh, (2000), on tomato.

The interaction effects of sulphur and phosphorus on potassium and sulphur contents displayed a similar trend to those of nitrogen and phosphorus, as reported above. The obtained results are in agreement with those of Olsen et al. (1993) on bell pepper; Mahmoud (2000) and Youssef (2002) who stated that the combined application of $\mathrm{P}$ and $\mathrm{S}$ to bell pepper plants progressively increased $\mathrm{N}, \mathrm{P}, \mathrm{K}, \mathrm{Ca}, \mathrm{Mg}$ and $\mathrm{S}$.

Table (5): Effect on sulphur, phosphorus and their interactions on macro element contents of sweet pepper leaves, during $2002\left(S_{1}\right)$ and $2003\left(S_{2}\right)$ seasons.

\begin{tabular}{|c|c|c|c|c|c|c|c|c|}
\hline \multirow{3}{*}{\begin{tabular}{|l} 
Characters \\
Season \\
Treatments \\
\end{tabular}} & \multicolumn{2}{|c|}{ N\% } & \multicolumn{2}{|c|}{ P\% } & \multicolumn{2}{|c|}{ K\% } & \multicolumn{2}{|c|}{ S\% } \\
\hline & S1 & S2 & S1 & S2 & S1 & S2 & S1 & S2 \\
\hline & & & & & & & & \\
\hline \multicolumn{9}{|c|}{$S(\mathrm{~kg} \mathrm{~S} / \mathrm{fed})$} \\
\hline Control & 3.45 & 3.58 & 0.394 & 0.429 & 2.81 & 2.47 & 0.12 & 0.14 \\
\hline 150 & 3.64 & 3.78 & 0.462 & 0.500 & 2.83 & 2.63 & 0.19 & 0.21 \\
\hline 300 & 3.79 & 3.96 & 0.556 & 0.582 & 3.07 & 2.80 & 0.25 & 0.28 \\
\hline L.S.D. (5\%) & 0.05 & 0.06 & 0.021 & 0.009 & 0.12 & 0.09 & 0.01 & 0.02 \\
\hline \multicolumn{9}{|c|}{$\mathrm{P}\left(\mathrm{kg} \mathrm{P}_{2} \mathrm{O}_{5} / \mathrm{fed}\right)$} \\
\hline Control & 3.28 & 3.47 & 0.359 & 0.401 & 2.43 & 2.14 & 0.12 & 0.15 \\
\hline 30 & 3.50 & 3.70 & 0.466 & 0.482 & 2.77 & 2.47 & 0.17 & 0.19 \\
\hline 60 & 3.77 & 3.92 & 0.513 & 0.542 & 3.07 & 2.83 & 0.21 & 0.24 \\
\hline 90 & 3.97 & 4.01 & 0.544 & 0.590 & 3.35 & 3.10 & 0.25 & 0.26 \\
\hline L.S.D. (5\%) & 0.06 & 0.03 & 0.020 & 0.014 & 0.07 & 0.05 & 0.02 & 0.01 \\
\hline \multicolumn{9}{|c|}{ Interactions } \\
\hline \multicolumn{9}{|l|}{\begin{tabular}{|l|l}
$\begin{array}{l}\text { S levels } \\
\text { (kg S/fed) }\end{array}$ & $\begin{array}{l}\text { P le } \\
\text { (kg }\end{array}$ \\
\end{tabular}} \\
\hline Control & 3.13 & 3.33 & 0.311 & 0.354 & 2.36 & 2.01 & 0.07 & 0.09 \\
\hline 30 & 3.31 & 3.49 & 0.387 & 0.408 & 2.75 & 2.29 & 0.11 & 0.13 \\
\hline tontrot & 3.59 & 3.70 & 0.433 & 0.455 & 2.90 & 2.64 & 0.14 & 0.16 \\
\hline Fonttre & 3.79 & 3.81 & 0.446 & 0.498 & 3.25 & 2.93 & 0.15 & 0.18 \\
\hline Control & 3.28 & 3.50 & 0.356 & 0.394 & 2.45 & 2.11 & 0.12 & 0.15 \\
\hline Gonttre & 3.50 & 3.69 & 0.462 & 0.481 & 2.62 & 2.45 & 0.16 & 0.18 \\
\hline 60 & 3.82 & 3.95 & 0.498 & 0.538 & 2.93 & 2.89 & 0.21 & 0.24 \\
\hline 90 & 3.96 & 4.00 & 0.530 & 0.587 & 2.93 & 2.89 & 0.21 & 0.24 \\
\hline Control & 3.42 & 3.59 & 0.411 & 0.455 & 2.48 & 2.29 & 0.18 & 0.20 \\
\hline 30 & 3.70 & 3.91 & 0.549 & 0.556 & 2.94 & 2.67 & 0.23 & 0.25 \\
\hline 60 & 3.89 & 4.11 & 0.608 & 0.632 & 3.38 & 2.95 & 0.28 & 0.31 \\
\hline 90 & 4.15 & 4.23 & 0.656 & 0.686 & 3.49 & 3.28 & 0.34 & 0.35 \\
\hline .S.D. $(5 \%)$ & 0.06 & 0.06 & 0.035 & 0.025 & 0.13 & 0.09 & 0.03 & 0.03 \\
\hline
\end{tabular}




\section{Leaf contents of microelements: \\ Effect of sulphur:}

Data in Table (6) display that iron, Zinc and manganese contents of the leaves were significantly increased as a result of increasing sulphur application. The increments were corresponded with the increase in the levels of sulphur. This was true in the two seasons of study.

The obtained results may be attributed to the positive effect of sulphur on the availability of micronutrients for plant uptake, through forming compounds which are capable in reducing soil $\mathrm{pH}$, and this in turn increases water penetration and improves soil structure which had a positive effect on the availability of nutrients such as $\mathrm{P}, \mathrm{Fe}, \mathrm{Zn}, \mathrm{Mn}$ and $\mathrm{Cu}$ (Hattar, 1983 and Shaheen and Omar, 1989).

Similar results were obtained by Topcuoglu and Yalcin (1997) who found that $\mathrm{Zn}, \mathrm{Mn}, \mathrm{Cu}$ and active $\mathrm{Fe}$ contents were increased in leaf petiole of tomato plants as a result of sulphur application. El-Fayoumy and El-Gamal (1998) and Youssef and Amer (2002) reported that $S$ application increased the availability and uptake of $\mathrm{Fe}, \mathrm{Mn}, \mathrm{Zn}$ and $\mathrm{Cu}$ in the leaves of potato. and pea plants.

\section{Effect of phosphorus:}

Results in Table (6) indicate that phosphorus fertilization had positive effect on the iron contents of pepper leaves. Data show that iron, zinc and manganese contents increased in the leaves of the treated plants over the control and the highest values were obtained with the medium level $(60 \mathrm{~kg}$ $\mathrm{P}_{2} \mathrm{O}_{5} / f e d$ ). This was evident in both seasons of study. Such data also reveal that the reduction in the $\mathrm{Fe}$ content at $\left(90 \mathrm{~kg} \mathrm{P}_{2} \mathrm{O}_{5} / \mathrm{fed}\right)$ compared with those of the medium level (60 $\mathrm{kg} \mathrm{P}_{2} \mathrm{O}_{5} / \mathrm{fed}$.) was significant, however, this reduction in $\mathrm{Zn}$ and $\mathrm{Mn}$ contents did not reach the level of significance. These results were confirmed by those of Sreenivasa et al. (1993), on Chili Pepper and Davies et al. (1999) on bell pepper who indicated that shoot $\mathrm{Zn}, \mathrm{Cu}, \mathrm{Mn}$ and Fe contents increased as applied $\mathrm{P}$ increased. Similar conclusion with $\mathrm{Zn}$ contents was obtained by Muthumanickam (2003) on black pepper.

\section{Effect of interaction:}

The interaction effects of sulphur and phosphorus levels on iron content (Table 6) indicated that leaves of plants treated with the highest level of sulphur (300 kg S/fed) and the medium level of phosphorus $\left(60 \mathrm{~kg} \mathrm{P} \mathrm{O}_{5} / \mathrm{fed}\right)$ gained significantly the highest contents of iron (251 and $232 \mathrm{ppm}$ ) in the first and second season, respectively, compared with those of control (141 and $111 \mathrm{ppm}$ ). Results of Table (6) also show that leaves of plants received (300 $\mathrm{kg} \mathrm{S} / \mathrm{fed})$ and $\left(60 \mathrm{~kg} \mathrm{P} \mathrm{P}_{5} / \mathrm{fed}\right)$ contained the highest levels of $\mathrm{Zn}$ (61 and 59 $\mathrm{ppm}$ )and $\mathrm{Mn}$ (79 and $71 \mathrm{ppm})$,), in the first and second seasons, respectively,

compared with control leaves that showed the lowest $\mathrm{Zn}$ contents (29 and 25 $\mathrm{ppm}$ ), and $\mathrm{Mn}$ (44 and $39 \mathrm{ppm}$ ), contents in the first and second season, respectively. However, differences in $\mathrm{Zn}$ and $\mathrm{Mn}$ contents, between treated and control plants, did not elevate to the significance level.

The combined effects of sulphur and phosphorus on leaf contents of microelements was confirmed by Fenn et al. (1990) and Singh et al. (1995). 
who stated that application of $\mathrm{S}$ and $\mathrm{P}$ to soil, reduced soil $\mathrm{pH}$ and and increased the availability and uptake of $\mathrm{P}, \mathrm{Fe}, \mathrm{Zn}, \mathrm{Mn}$ and $\mathrm{Cu}$.

Table (6). Effect of sulphur, phosphorus and their interactions on microelement contents of sweet pepper leaves, during 2002 (S1) and 2003 (S2) seasons.

\begin{tabular}{|c|c|c|c|c|c|c|c|}
\hline \multirow{2}{*}{\begin{tabular}{|l|} 
Characters \\
Season \\
\end{tabular}} & & \multicolumn{2}{|c|}{ Fe (ppm) } & \multicolumn{2}{|c|}{ Zn (ppm) } & \multicolumn{2}{|c|}{ Mn (ppm) } \\
\hline & & S1 & S2 & S1 & S2 & S1 & S2 \\
\hline \multicolumn{8}{|l|}{ Treatment } \\
\hline \multicolumn{8}{|c|}{ S (kg S/fed) } \\
\hline Control & & 166 & 151 & 38 & 33 & 49 & 43 \\
\hline 150 & & 199 & 177 & 45 & 41 & 63 & 53 \\
\hline 300 & & 232 & 204 & 53 & 50 & 72 & 63 \\
\hline L.S.D. (5\%) & & 8.28 & 3.60 & 3.51 & 5.37 & 3.12 & 5.01 \\
\hline \multicolumn{8}{|c|}{$\mathrm{P}\left(\mathrm{kg} \mathrm{P} \mathrm{O}_{5} / \mathrm{fed}\right)$} \\
\hline Control & & 174 & 150 & 36 & 32 & 55 & 46 \\
\hline 30 & & 192 & 174 & 42 & 38 & 60 & 52 \\
\hline 60 & & 221 & 201 & 53 & 50 & 66 & 59 \\
\hline 90 & & 209 & 185 & 50 & 47 & 64 & 55 \\
\hline L.S.D (5\%) & & 5.79 & 4.47 & 4.23 & 4.33 & 3.55 & 3.39 \\
\hline \multicolumn{8}{|c|}{ Interactions } \\
\hline \multirow[t]{2}{*}{$\begin{array}{l}\text { S levels } \\
\text { (kg S/fed) }\end{array}$} & $\begin{array}{l}\text { P Levels } \\
\left(\text { kg P } \mathrm{P}_{2} \mathrm{O}_{5} / \mathrm{fed}\right)\end{array}$ & & & & & & \\
\hline & Control & 141 & 111 & 29 & 25 & 44 & 39 \\
\hline & 30 & 152 & 150 & 35 & 30 & 49 & 41 \\
\hline - & 60 & 192 & 178 & 47 & 42 & 53 & 48 \\
\hline conntret & 90 & 179 & 166 & 42 & 38 & 50 & 45 \\
\hline 6entrot & Control & 178 & 159 & 38 & 32 & 59 & 47 \\
\hline & 30 & 190 & 173 & 42 & 39 & 62 & 52 \\
\hline 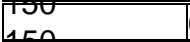 & 60 & 220 & 195 & 53 & 49 & 68 & 60 \\
\hline $\begin{array}{l}120 \\
15 t\end{array}$ & 90 & 211 & 183 & 50 & 47 & 65 & 54 \\
\hline t5 & Control & 203 & 180 & 43 & 39 & 63 & 52 \\
\hline & 30 & 235 & 200 & 50 & 46 & 71 & 63 \\
\hline 80 & 60 & 251 & 232 & 61 & 59 & 79 & 71 \\
\hline (l) & 90 & 239 & 206 & 59 & 56 & 77 & 67 \\
\hline D (5\%) & & 10.02 & 12.49 & N.S. & N.S. & N.S. & N.S. \\
\hline
\end{tabular}

\section{REFERENCES}

Alabi, D.A. 2006. Effects of fertilizer phosphorus and poultry droppings treatments on growth and nutrient components of pepper (Capsicum annuum L.). Afri. J. Biotechnology 5(8): 671-677.

Al-Rawi, A.A. and M.M. Tajuldeen. 1985. Effect of sulphur on the availability of nutrient elements in some calcareous soils. Proc. $2^{\text {nd }}$ Arab. Regional Conf. on sulphur and its usages in Arab Countries, 1: 71-92.

Black, C.A. 1965. Methods of soil analysis Part 1. Physical and Mineralogical properties. A.S.A. Madison, Wisc., USA.

Black, C.A. 1983. "Methods of soil analysis" Part I and II. Amer. Soc. Agron. Inc. Publ., Madison, Wisc., USA. 
Broschat, T.K. and M.K.A. Klock. 2000. Root and shoot growth responses to phosphate fertilization in container-grown plants. Hort Technology, 10(4): 765-767.

Chapman, H.D. and P.F. Partt. 1961. Methods of analysis for soil, plant and water. Department of Soil and Plant Nutrition, Univ. of California, Citrus Exp. Sta. Reverside, California.

Dahdouh, S.M., N.N. Youssef and A.S. Metwally. 1993. Sulphur and chicken manure interactions in relation to yield and availability of macro and micronutrients to tomato grown on calcareous soil. Egypt. J. Appl. Sci., 8: 638-653.

Davies, F.T.J., S.A.Duray, L. Phavaphuthnon and R.S. Stahl. 1999. Influence of phosphorous on gas exchange and plant of two morphologically distinct types of Capsicum annuum. Photosyn. 36(1-2): 99-106.

Dietz, K.J. 1989. Recovery of spinach leaves from sulphate and phosphate deficiency. J. Plant Physiol. 134: 551-557.

El-Fayoumy, M.E. 1996. Response of highly calcareous soils and faba bean crop to sulphur mixed with organic manure application. J. Agric. Mansoura Univ., 21: 1183-1191.

El-Fayoumy, M.E. and A.M. El-Gamal. 1998. Effects of sulphur application rates on nutrients availability, uptake and potato quality and yield in calcareous soil. Egypt, J. Soil Sci. 38(1-4): 271-286.

El-Ghamry, A.M., Z.M. El-Sirafy and R.A. El Dissoky. 2005. Response of potato grown on clay loam soil to sulfur and compost application. J. Agric. Sci. Mansoura Univ. 30(7): 4337-4353.

El-Morsy, A.H.A., A.E. Abdel-Fattah and Z.S.A. El-Shal. 2002. Effect of phosphate fertilizer and vascular mycorrhizal inoculation on growth, tuber yield and quality of sweet potato. Proc. Minia 1 st Conf. for Agric. \& Environ. Sci. Minia, Egypt. March 25-28.

El-Morsy, A.H.A. 2005. Effect of sulphur levels and foliar application of certain micronutrients on garlic (Allium sativum L.) The $6^{\text {th }}$ Arabian Conference for Horticulture, Ismailia, Egypt March 20-22.

El-Tohamy, W.A., A.A. Ghoname and S.D. Abou-Hussein. 2004. Improvement of pepper growth and productivity in sandy soil by different fertilization treatments under protected cultivation. Annals. Agric. Sci. Cairo. 49(1): 243-252.

Fenn, L.B., H.L. Mistom, T. Riley and G.L. Horst. 1990. Acidification of calcareous soils improves zinc absorption of crops. J. Amer. Soc. Hort. Sci. (115): 741-744.

Fenn, L.B., R.M. Taylor and C.A. Pety. 1987. Stimulative effects of elemental sulfur in the presence of ammonium on chili and broccoli growth on calcareous soils. J. Plant Nut. 10(17): 2263-2281.

Gardener, F.D., R.B. Pearce and R.L. Mitchell. 1985. Physiology of crop plants. The lowa State Univ. Press, Amer. 327.

Gendy, E.N., S.A.A. El-Raies and M.A. Abdel Reheem. 1995. Effect of number of irrigation and sulphur application on broad been growth and yield. Egypt. J. Soil Sci. 35: 379-393. 
Gopal, R., P. Sinha, B.K. Dube and C. Chatterjee. 2003. Phosphorus sulphur interaction in tomato (Lycopersicon esculentum L.) metabolism. Ind. J. Hort. 60(3): 244-250.

Hattar, B.I. 1983. Effect of elemental sulfur and $\mathrm{H}_{2} \mathrm{SO}_{4}$ addition on active $\mathrm{CaCO}_{3}$ and micronutrients in calcareous soils. Agronomy Annual Meetings. Washington, D.C., 171.

Hewedy, A.M. 1999. Effect of sulphur application and biofertilizer phosphoren on growth and productivity of tomato. Minufiya J. Agric. Res. 24(3): 10763-10787.

Hilal, M.H. 1990. Sulphur in desert Agro - Systems. Proceedings Middle East Sulphur Symposium 12-16 February, Cairo, Egypt, 19-50.

Jackson, M.L. 1965. Soil chemical analysis advanced course Publ. By Author, Madison, Wisconsin, U.S.A.

Jaggi, R.C., V.K. Suri and S.P. Dixit. 2003. Comparative performance of sulphur containing and non-containing phosphorus fertilizers on dry chilli (Capsicum annuum) in acid Alfisol. Ind. J. Agric. Sci. 73(1): 49-50.

Kaya, C., D. Higgs, F. Ince, B.M. Amador, A. Cokir and E. Sakar. 2003. Ameliorative effects of potassium phosphate on salt-stressed pepper and cucumber. J. Plant Nut. 26(4): 807-820.

Khater, A.M.H. 1981. A study of sulphur and petroleum by-products as efficient materials affecting the availability of certain nutrients in soils. M.Sc. Thesis, Fac. Agric. Ain Shams Univ.

Koller, H.R. 1972. Leaf area-leaf weight relationship in the Soybean Conopy. Crop. Sci. (12): 180-183.

Kowalska, I. 2005. Effects of sulphate level in the nutrient solution on plant growth and sulphur content of tomato plants. Folia-Horti. 17(1): 91-99.

Lauer, M.J. ; D. G. Blevins and H. Sierzputowska - Graiz, 1989, ${ }^{31} \mathrm{P}$ nuclear magnetic resonance determination of phosphoate compartmentation in leaves of reproductive soybeans (Glycine Max L) as affected by phosphate nutrition. Plant Physiol. 89: $1331-1336$.

Lopez-Moreno, J., N. Tremblay, W. Voogt, S. Dube and A. Gosselin. 1996. Effects of varying sulphate concentrations on growth, physiology and yield of the greenhouse tomato. Scientia Horticulturae. 67(3-4): 207217.

Mackinny, G. 1941. Absorption of light by chlorophyll solution. J. Biol. Chem. 140: 315-322.

Mahmoud, H.A.F. 2000. Effect of sulphur and phosphorus on some eggplant cultiva

under calcareous soil conditions. Bull. Fac. Agric. , -Univ. of-Cairo. 51(2): 209-225.

Mazrouh, A.Y. 2000. Response of tomato to phosphorus and sulphur application under the conditions of salt affected soils. J. Agric. Res., Tanta Univ. 26(2): 391-403.

Mehana, T.A. 1994. Microbiological properties and nutrient availability in a salt affected calcareous soil as influenced by certain amendments under leaching conditions. Bull. Suez Canal Univl. Appl. Sci., 3: 348362. 
Mehana, T.A. and F.M. Farag. 2000. Influence of phosphate-dissolving microorganisms and elemental sulphur on phosphorus and micronutrient availability in a calcareous soil treated with rock phosphate. J. Agric. Sci. Mansoura Univ., 25(5): 2983-2993.

Morris, R.G., S.L. Tisdal and J. Platou. 1984. The importance of sulphur in crop quality. J. Fert. Issmes, 1: 139-145.

Mostafa, M.A., A.M. El-Gala, M. Wassif, S.E. El-Maghraby and M.H. Hilal. 1990. Distribution of some micronutrients through a calcareous soil columns under sulphur and saline water application. Proceedings Middle East Sulphur Symposium, 12-16 Feb., Cairo, Egypt, 263-276.

Muthumanickam, D. 2003. Influence of different phosphorus sources and zinc spray on the yield and quality of black pepper (Piper nigrum L.) under acid soils. J. Spices and Aromatic Crops. 12(1): 15-18.

Nigri, F.M., S. Vazquez and I.A. Morales. 1999. Fertilization of pepper (Capsicum annuum L.) with NPK under plastic cover. Hort. Argentina. 16(40-41): 64-67.

Olsen, J.K., P.J. Lyons and M.M. Kelly. 1993. Nitrogen uptake and utilization by bell pepper in subtropical Australia. J. Plant Nut. 16(1): 177-193.

Omar, N.M., A.M. Shaheen and M.O. Bakry. 1990. The residual effect of sulphur and phosphorus fertilization on the growth and yield of pea (Pisum sativum L.) plants. Egypt. J. Agron., 15(1/2): 87.

Page, A.L. 1982. Methods of soil analysis Part 2. Chemical and microbiological properties (2 ${ }^{\text {nd }}$ ed.). Agron. J. Amer. Soc. Agron., Inc. Publ., Madison, Wis. USA.

Pandey, J. and M. Agrawal. 1994. Growth responses of tomato plants to low concentrations of sulphur dioxide and nitrogen dioxide. Sci. Hort. 58(12): 67-76.

Radwan, E.A. and A.A. Tawfik. 2004. Effect of sulphur, manganese and zinc on growth, yield and quality of potato (Solanum tuberosum L.) J. Agric. Sci. Mansoura Univ. 29(3): 1423-1431.

Rahman, M. and M.M. Hoque. 1994. Yield response of brinjal (Solanum melongena L.) to sulphur fertilizer. Bangladesh J. Sci. and Indust. Res. 29(4): 151.

Reuveni, R., G. Dor and M. Reuveni. 1998. Local and systemic control of powdery mildew (Leveillula tourica) on pepper plants by foliar spray of monopotassium phosphate. Crop prod. 17(9): 703-709.

Rivera, E. and H. Irgazarry. 1984. Effect of fertilization with phosphorus, sulphur and micronutrients on yields of peppers growing on an alkaline soil. J. Agric. Univ. Puerto - Rico. 68(1): 1-4.

Sawan, O.M. and F.A. Rizk. 1998. The productivity of eggplant (Solanum melongena L.) as affected by the element and NPK mixture. Egypt. J. Hort. 25(1): 1-16.

Schroeder, M.S. and D.P. Janos. 2005. Plant growth, phosphorus nutrition, and root morphological response to arbuscular mycorrhizas, phosphorus fertilization, and intraspecific density. Mycorrhiza. (15): 203-216. 
Shaheen, A.M., M.O. Bakry and M.M. Abou El Maged. 1989a. Response of growth and yield of broad bean (Vicia faba L.) plants to phosphorus and sulphur application. Egypt. J. Appl. Sci., 4(1): 37-83.

Shaheen, A.M. and N.M. Omar. 1989. The elemental fertilization by sulphur and nitrogen their effects on growth and yield of sweet pepper (Capsicum annuum L.) plants. J. Agric. Sci. Mansoura Univ. 14(3): 1692-1699.

Shaheen, A.M., T.T. El-Labban and N.M. Omar. 1989b. Studies on the growth and yield of sweet pepper (Capsicum annuum L.) plants as affected by sulphur and phosphorus nutrition. African J. Agirc. Sci. 16(1-2): 213.

Singh, J.P., R.S. Marwaha and O.P. Srivastava. 1995. Processing and nutritive qualities of potato tubers as affected by fertilizer nutrients and sulphur application. J. Indian Potato Assoc. 22(1-2): 32-37.

Smatanova, M., R. Richter and J. Hluesk. 2004. Spinach and pepper response to nitrogen and sulphur fertilization Plant Soil and Env. 50 (7): 303-308.

Snedecor, C.W. and W.G. Cochran. 1980. Statistical Methods $7^{\text {th }}$ ed. lowa State Univ. Press, p. 504.

Sreenivasa, M.N., P.U. Krishnaraj, G.A. Gangadhara and H.M. Manjunathaiah. 1993. Response of chilli (Capsicum annuum L.) to the inoculation of an efficient vesicular - arbuscular mycorrhizal fungus. Sci. Hort. 53(1-2): 45-52.

Taylor, R., L. Fenn and C.A. Pety. 1984. Preliminary observations of chili plant response to banded sulfur. J. Fert. Issues. 1(4): 146-149.

Tisdale, S., W. Nelson, I. Beaton and J. Havlin. 1995. Soil Fertility and Fertilizers. $5^{\text {th }}$ Macmillan Publishing Company, New York. 266-289.

Topcuoglu, B. and S.R. Yalcin. 1997. Effects of elemental sulphur applications to calcareous soil on yield and quality properties and some plant nutrient contents of tomato plant grown under covered conditions. Ziraat-Fakultesi-Dergisi, -Akdeniz-Universitesi. 10(1): 196-210.

Vinay, S., A. Singh and V.S. Metha. 1995. Effect of sulphur sources and levels on yield and uptake of nutrients by garlic. Fert. News. 40(8): 4749.

Watanab, F.S. and S.R. Olsen. 1965. Test of ascorbic acid method for determining phosphorus and $\mathrm{NaHCO}_{3}$ extracts for soil. Soil Sci. Soc. Amer. Proc. 29: 677-678.

Yousry, M., A. El-Leboudi and A. Khater. 1984. Effect of sulphur and petroleum by products on soil characteristics. 11. Availability of some nutrients in a calcareous soil. Egypt. J. Soil Sci., 24(3): 195-200.

Youssef, A.M. 2002. Growth and yield of pea (Pisum sativum L.) plants as affected by application of sulphur and NPK mixture. J. Agric. Sci. Mansoura Univ. 27(9): 1099-2002.

Youssef, A.M. and A.S.S. Amer. 2002. Response of pea plants (Pisum sativum L.) to supplement of sulphur to the soil and foliar application on some micronutrients. J. Agirc. Sci. Mansoura Univ., 27(9): 1083-1098. 


\section{تأثير استعمال الكبريت المعدني و التسميد الفوسفاتي علي نمو و محصول و جودة ثمار الفلقل الحلو الثئو \\ أـ النمو الخضري و المحتوي الكيماوي للأوراق \\ خفاجي عبد الرحد حسن رخاء** - محمود عبد المحسن حسن* - سمير كامل الصيفي *محد

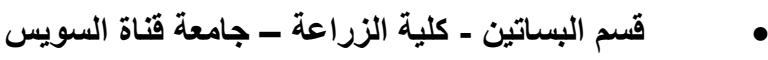

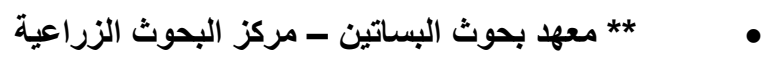

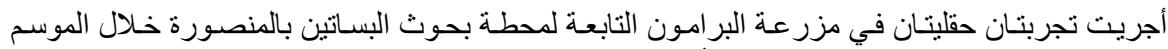

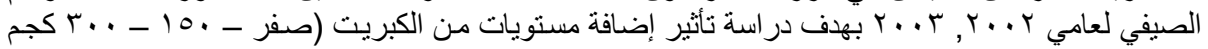

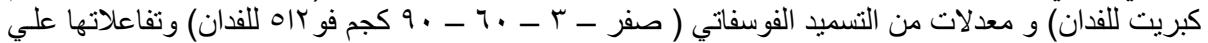

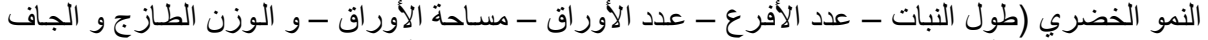

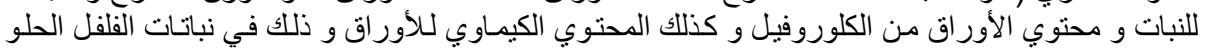

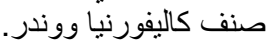

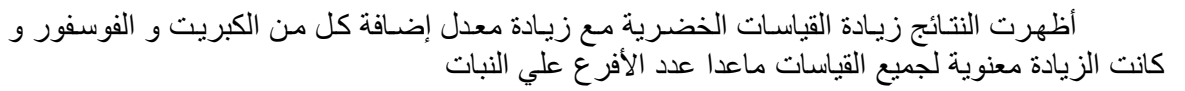

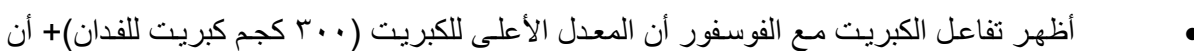

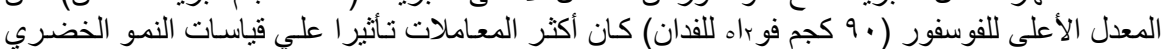
بالمقارنة بباقي المعاملات و ذللك خلال عامي الدراسة

زاد محتوي الأوراق من كلوروفيل ا بـ و الكلوروفيل الكلي و نسبة كلوروفيل ا/ب زيادة معنوية الكية

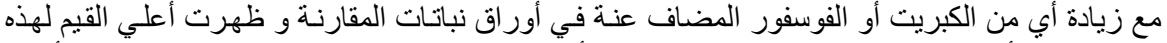

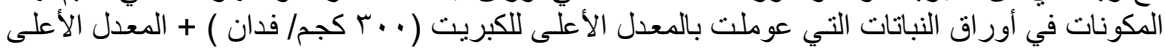

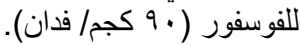

أظهر محتوي الأوراق من عناصر النيتروجين , الفوسفور , البوتاسيوم و الكبريت زيادة معنوية الكبادية

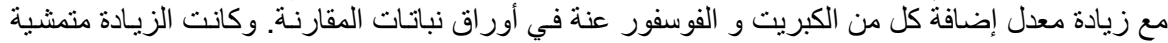

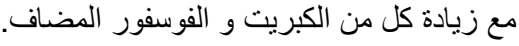

أظهر تفاعل الكبريت مع الفوسفور أعلي محتوي لهذه العناصر في أوراق النباتات التي تم تسميدها بالمعدل الأعلى لكل من الكبريت و الفوسفور.

ظهر أعلى محتوي للأوراق من عناصر الديد , المنجنيز في أوراق النباتات التي تم تسميدها

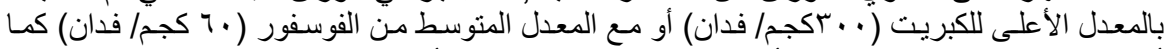

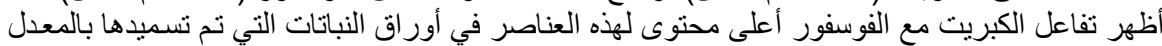

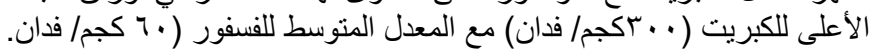

